\title{
Mortal Ancestors, Immortal Images: Zhang Dai's Biographical Portraits
}

\author{
Duncan M. Campbell, Australian National University
}

\begin{abstract}
Nobody looking at paintings and who sees a picture of the Three Sovereigns and the Five Emperors fails to be moved to respect and veneration, or, on the other hand, to sadness and regret when seeing pictures of the last rulers of the Three Dynasties. Looking at traitorous ministers or rebel leaders sets one's teeth grinding whereas, on sight of men of integrity or of great wisdom, one forgets to eat, on sight of loyal ministers dying for their cause one is moved to defend one's own integrity ... From this consideration does one understand that it is illustrations and paintings that serve to hold up a mirror to our past in order to provide warnings for our future course of action.（觀畫者見三皇五帝莫不仰戴見三季異主莫不悲惋見篡臣賊嗣莫不切齒見高節 妙士莫不忘食見忠臣死難莫不抗節…是知存乎鑒戒者圖畫也)

Cao Zhi 曹植 (192-232), quoted in Zhang Yanyuan 張彥遠 (9 $9^{\text {th }}$ Century), Lidai minghua ji 歷代名畫記 [A Record of Famous Paintings Down Through the Ages]
\end{abstract}

In keeping with the name it took for itself (ming 明, brilliant, luminous, illustrious), the Ming dynasty (1368-1644) was a moment of extraordinary development in the visual cultures of the traditional Chinese world (Clunas 1997; 2007). ${ }^{1}$ On the one hand, this period of Chinese history saw internal developments in various aspects of preexisting visual culture; on the other, through developments in xylography and commercial publishing in particular, but also through the commoditization of the objects of culture generally, the period also saw a rapid increase in the dissemination and circulation of

\footnotetext{
${ }^{1}$ Clunas writes: 'The visual is central in Ming life; this is true whether it is the moral lecturer Feng Congwu (1556-?1627) using in his impassioned discourses a chart showing a fork in the road, one path leading to good and one path to evil, or in the importance in elite life of dreams as "visions," one might say as "visual culture," since they made visible, to the dreamer at least, cultural assumptions about fame and success' (2007: 13). I wish here to acknowledge the enormous help and encouragement given me in the preparation of this paper by Professor Geremie Barmé, Dr Claire Roberts, and, particularly, Professor Maurizio Marinelli. The comments offered by the two anonymous readers of the paper have also been immensely helpful in demanding of the paper a somewhat sharper focus.
}

PORTAL Journal of Multidisciplinary International Studies, vol. 9, no. 3, November 2012. Politics and Aesthetics in China Special Issue, guest edited by Maurizio Marinelli. ISSN: 1449-2490; http://epress.lib.uts.edu.au/ojs/index.php/portal PORTAL is published under the auspices of UTSePress, Sydney, Australia. 
images of one sort or another, both throughout the empire and beyond. ${ }^{2}$ If the medium of the late imperial Chinese image as it circulated was not entirely new, its ubiquity nonetheless was certainly unprecedented. Understandably, much of the relevant secondary literature, in both Chinese and English, has focused on painting, particularly on developments in the method and value of portrait painting, once such an important aspect of painting in China but which from around the tenth century onwards had been completely replaced by, particularly, landscape painting as the predominant and most prestigious form (Vinograd 1992). More recently, and addressing the other end of the usual hierarchy of the arts in China, attention has also been given woodblock book illustration (Hegel 1998; Burkus-Chasson 2010).

In both these respects, portrait painting and woodblock illustration, the late Ming loyalist painter Chen Hongshou 陳洪綬 (1598-1652) has been regarded as a critical figure. ${ }^{3}$ Speaking of Chen's self-portraits, for instance, James Cahill argues that: 'Late Ming people can be said to inhabit works of art ... but the relationship and the effect are dramatically different [from earlier models]: they typically appear more like people who have taken refuge in the realm of art from a world in which they have no secure place, and who find that the realm of art does not receive them comfortably either. They look out at us as if compelled by some need to assert their existence as individuals, to communicate some sense of their situation' (1982: 124).

What was particular about Chen's situation? If the first forty-six years of his life had been marred by the sorts of misfortunes that could befall anyone of his age (being orphaned early, repeated examination failure at the provincial level, premature death of his wife, and so on), the fall of the Ming dynasty in 1644 added layers of guilt and regret to the way that he thought of himself during his last decade, certainly as he represented himself in the numerous pseudonyms he took after this date: 'Old and Too Late’ (Laochi 老遲), 'Repentant Monk’ (Huiseng 悔僧), 'Repentance Too Late’ (Huichi 悔遲), and so on. As Cahill writes, whereas others in his circumstances either resisted the invaders or committed suicide, Chen Hongshou 'wept loudly and got drunk and

\footnotetext{
${ }^{2}$ One particular illustration of the increasing importance of the visual during the late Ming period especially is the proliferation of painting manuals, an aspect that has recently received excellent treatment in Park (2012). K. T. Wu (1943: 203) argues that Chinese print culture saw four particular developments in the course of the Ming dynasty (colour printing, woodblock illustrations, the use of copper movable type, and the production of xylographic facsimiles of earlier editions), all of which have implications for an understanding of the visual during this age.

${ }^{3}$ For a short English-language biography of this man, see Hummel (1943: 87-88).
} 
acted so strangely that people thought he was crazy' (1982: 140). 'The portraits and figure paintings' of Chen Hongshou and others, Cahill concludes, 'can be seen as determined, even desperate attempts to reestablish the old ideal, the interpenetration of past and present, culture and life. But they also stand as admissions of an awareness that the old formula could no longer be made to work' (1982: 145).

In literary terms, and with particular respect to developments in biographical and autobiographical writing, the man who in this late Ming world sought hardest to assert the existence of individuality, his own as well as of his contemporaries, and to communicate to later generations something of the plight they faced was one of Chen Hongshou's oldest and closest friends, the essayist and historian Zhang Dai 張岱 (1597?1684), a man who had also chosen, problematically, after having 'misspent' the first half of his life, to take refuge from the world in the realm of art (and dream). ${ }^{4}$

In the extensive forty-year-long biographical enterprise Zhang Dai set himself after the collapse of the Ming, he inherits the search for the 'presence beyond death' that lies at the heart of all traditional biographical writing in China. To Zhang Dai, however, this promise of immortality appears not to have been vouchsafed only in 'Virtue' (de 德), 'Deed' (gong 功) and 'Word' (yan 言), the establishment of which (li 立) in the course of one's life was traditionally held to constitute the 'Three Eternals' of a life well lived (sanbuxiu 三不朽). ${ }^{5}$ Rather, it was to be found in the very complexity and ambivalence of the human condition itself, particularly in times of disorder. For him too, the

\footnotetext{
${ }^{4}$ For short English-language biographies of Zhang Dai, see Hummel (1943: 53-54); and Nienhauser (1986: 220-21). In Chinese, see Xia Xianchun (1989); Hu Yimin (2002a); Hu Yimin (2002b); She Deyu (2006); and Zhang Zetong (2009). Kafalas (1998: 50-85) provides a suggestive discussion of Zhang Dai's Taoan mengyi [Dream Memories of Taoan]. Spence (2005: 1-10) presents a characteristically insightful reading of Zhang Dai's family biographies. Both Kafalas and Spence have subsequently published full-length treatments of Zhang Dai: Kafalas (2007) and Spence (2007). Hegel (2006: 345-74) discusses Zhang Dai and his literary endeavours. If the exact time and date of Zhang Dai's birth (dawn of the $15^{\text {th }}$ day of the $8^{\text {th }}$ month of the Dingyou year of the reign of the Wanli emperor), as he noted in his 'Ziwei muzhiming' 自為墓志銘 [My Own Epitaph] (Zhang Dai 1985: 200) is uncontested, the year of his death remains problematical, with proposed dates ranging from as early as 1665 to as late as 1689 , for which, see He Guanbiao (1986: 167-93). Hu Yimin (2002b) argues that the latest possible date for his death is the winter of 1680 , during his $84^{\text {th }}$ year, whereas Xia Xianchun (Zhang Dai 1991: 1) settles on 1684 as the most likely date.

${ }^{5}$ The locus classicus for this expression is the Zuo zhuan 左傳 [Zuo Commentary] ( $24^{\text {th }}$ year of Duke Xiang) where Fan Xuanzi inquires of Mushu what is intended by the saying of the ancients 'They died but suffered no decay.' His reply was: 'I have heard that the highest meaning of it is when there is established [an example of] virtue; the second, when there is established [an example of] successful service; and the third, when there is established [an example of wise] speech. When these examples are not forgotten with length of time, this is what is meant by the saying-"They do not decay"' (Legge 1960: $5,507)$.
} 
biographical investigation of the lives of his friends and his family was also a pursuit of an understanding — and representation — of his own self. ${ }^{6}$ As I have recently argued elsewhere (Campbell 2010), their authenticity is to be discovered in the flaws (xia 㩔) of his friends and family members, and the knowledge and virtue of history is arrived at only to the extent to which the historian, when writing about his own family and friends particularly, does not allow his vision to be clouded by his fear, his gratitude, or his tenderness, as Samuel Johnson once counseled in his 'The Dignity and Usefulness of Biography.'

As both historian and essayist, Zhang Dai was interested in affect: in the look, the taste, the smell, the sound and the feel of the past, the force of our sensory impressions in the memory. Above all, however, he was aware of how fraught and difficult was any attempt to capture these fleeting impressions in either word or image.

In one of the last datable pieces he wrote, for instance, his memory stretches back to encompass the sound that accompanied his own birth: 'It has been eighty-one long years now since I left my mother's womb. Frequently, in quiet moments when my ears are not otherwise occupied, I find that it is as if they ring with the sound of her voice reciting the sutras. When still young, it seems, my mother had made a vow in which she promised to recite all 36,000 verses of the Sutra of the White-Robed Guanyin were she to be granted a son. So it was, then, that I was born wrapped in double afterbirth and the sound of this sutra being recited has accompanied me throughout my life ever since. Although I have subsequently lived through the chaos of warfare, this sound has never disappeared from my ears' (岱離母胎八十一年矣常常於耳根清淨時恍聞我母念經之聲蓋以我 母年少祈嗣許念白衣觀音經三萬六千卷也故岱生時遂有重胞之異此經聲是胎裡帶來雖遭劫火燒之 不失也). ${ }^{7}$

\footnotetext{
${ }^{6}$ For recent treatment of this aspect of Zhang Dai's work, see Campbell (2010: 25-55). Zhang Dai's biographical enterprise, particularly with respect to his family, is open to other readings. Spence (2005: 3$)$, for instance, makes a very convincing case for an understanding of the biographies discussed above as metaphor for the collapse of the Ming dynasty: 'Yet even as I am accepting Zhang Dai's biographies on their own terms, I am conscious that they insistently point us to another level of interpretation, one in which these biographical family sketches are also - or could it be 'are mainly'? — about the fall of the Ming and what came before that fall. The Zhang family is depicted as fragmenting, groping for standards, losing its sense - so clear in great great-grandfather's day - of where it is going. The rout and flight of the Ming is echoed by the rout and flight of the Zhangs ... Zhang, in other words, writes as a fugitive and a survivor. His role is to conjure up the lives and the age that are gone, and to hold all of them up to rigorous standards of scrutiny.'

7 'Baiyi guanyin zan bing xu' 白衣觀音贊並序 [Encomium on The White Robed Guanyin, with Preface] (Zhang Dai 1985: 245). Unless otherwise noted, all translations from Chinese that follow are my own.
} 
Very often, however, the pleasures afforded us by our sensory impressions are altogether too fleeting and unrecoverable, quite beyond the power of memory and therefore no longer susceptible to capture. 'Once, when watching a marvellous opera, I was overcome with a sense of remorse that I could not wrap the performance up in finest brocade so that it could be passed on and thus become immortal,' Zhang Dai tells us. 'This feeling I liken to what we experience when we happen to catch a glimpse of a bright moon hanging high within the sky, or as we savour the taste of a freshly-brewed cup of fine tea, both things that can provide us the gratification of but a moment, their passing to then occasion a lifetime's regret at their passing' (余嘗見一出好戲恨不得法錦包 裹傳之不朽嘗比之天上一夜好月與得火候一杯好茶只可供一刻受用其實珍惜之不盡也). ${ }^{8}$

In keeping with these considerations, Zhang Dai's auto/biographical writing is characterized by a quest for biographical verisimilitude, for, in his words, that 'sense of authenticity' (zhenqi 真氣) ${ }^{9}$ that would thus lend his subjects their immortality. This quest actuated both the biographies later gathered in his collected works, as well as those that form the bulk of his largest historiographical project, the monumental Shigui $s h u$ 石匮書 [Book of the Stone Casket], which he embarked upon in 1628 and only managed to complete, in the most difficult of circumstances, in 1655. Interestingly, however, both his earliest excursion into the field of biographical writing, his Gujin yilie zhuan 古今義烈傳 [Biographies of the Martyrs Ancient and Modern], the preface of which is dated 1628 and which was the only one of his books to have been published in his lifetime, and the book he was working on when he died, entitled Ming yuyue sanbuxiu mingxian tuzan 明於越三不朽明賢圖贊 [Portraits of the Eminent Worthies of Zhejiang During the Ming Dynasty Whose Lives Embodied the Three Eternals] (hereafter, Portraits) and the focus of this present paper, appear to work to starkly different principles from those seen at work in the bulk of his biographical portraits. ${ }^{10}$ In this paper I seek to understand this difference, by looking particularly at the manner in which he represents a number of his friends and family members in this last work. I start

\footnotetext{
8 'Peng Tianxi chuanxi’ 彭天錫串戲 [Peng Tianxi as Performer] (Zhang Dai 2001: 93).

${ }^{9}$ This term derives from Zhang Dai's famous claim that: "One cannot befriend a man who is without an obsession for he lacks deep emotion; one cannot befriend a man who is without a flaw for he is without any sense of authenticity” (人無癖不可與交以其無深情也人無疪不可與交以其無真氧), for which see, 'Qi Zhixiang pi' 祁止祥癖 [Qi Zhixiang's Obsessions] (Zhang Dai 2001: 72). The epigram is repeated verbatim in Zhang Dai's 'Wu yiren zhuan'五異人傳 [Biographies of Five Eccentrics] (Zhang Dai 1985: 175).

${ }^{10}$ This last work enjoyed a variety of titles over time; in this paper I have standardised my references to it under this title.
} 
with a brief consideration of Zhang Dai's verbal quest for verisimilitude, before turning to consider the particular conjunction of word and image found in Portraits.

'All my life I have disliked writing flattering epitaphs,' Zhang Dai claimed, 'and when, occasionally, I have been prevailed upon to compose epitaphs, I have always tried to ensure that my portrait of the person concerned fully captured a true likeness of them (kuxiao 酷肖), thus often managing to displease the people who requested the epitaph in the first place. Although many times I've thought about turning over a new leaf in this respect, sadly, I have never managed to do so., ${ }^{11}$

To this end and to a greater or lesser extent, all the biographies found included in Zhang Dai's collected works and his histories serve to expose details of the lives of their subjects that might appear unflattering or unsightly and reveal a biographer at work in a context whereby he had become a 'remnant subject' (yimin 遺民) and whose decision to live through the dynastic collapse of the 1640s resulted in a forty-year-long and guiltridden attempt to recapture in words the splendours of the late-Ming world he had so indulged himself within. ${ }^{12}$ It was an age during which a 'large touchstone had fallen from Heaven' (shang tian jiangxia yikuai da shijinshi 上天降下一塊大試金石) that now served to reveal the 'true face' (zhenmian 真面) of his contemporaries, a 'grand year-end settling of all accounts' (guonian qingxiao zhangmu 過年清銷賬目), Zhang Dai tells us. Others spoke of a 'time when Heaven consisted entirely of blood' (mitian jie xue zhi shi 濔天皆血之時) or when 'the Earth broke apart and Heaven crumbled, the very sun and moon began to darken' (diche tianbeng riyue hun 地坼天崩日月昏). The high drama and tragedy of the age was lent an air of theatricality by the importance ascribed, after the fall of the dynasty and the imposition of Manchu authority, to both hairstyle and the cut of one's gown.

\footnotetext{
11 'Zhou Wanwei muzhiming' 周宛委墓志銘 [Epitaph for Zhou Wanwei] (Zhang Dai 1985: 203).

${ }^{12}$ A number of Zhang Dai's friends chose otherwise: Qi Biaojia 衩趁佳 (1602-45; see Hummel (1943: 126)) drowned himself in the lake in his Allegory Garden, for instance, whereas Huang Daozhou 黄道周 (1585-1646; Hummel (1943: 345-47)), one of Zhang Dai's 'Friends in Historiography' (shixue zhiji 史學 知已), was executed having first tried unsuccessfully to starve himself to death. All three of Zhang Dai's 'Friends in Ancient Prose' (guwen zhiji 古文知已) committed suicide: Wang Siren 王思任 (1575-1646; Goodrich \& Fang (1976: 2: 1420-25)) barred the door of his study and starved himself to death; Ni Yuanlu 倪元璐 (1593-1644; Hummel (1943: 587)) hung himself upon the fall of Beijing to the rebel leader Li Zicheng 李自成 (1605-45); and Chen Hanhui 陳函輝 (1589-1645) leapt into the Yangtze River upon the fall of Nanjing. For discussions of the choices presented men of this time, see Struve (1982: 231-266); Fisher (1984: 83-122); Wakeman (1984: 631-665); and Ho (1994: 123-151).
} 
Zhang Dai addresses aspects of the difficulties posed by biographical writing at the very beginning of his collective biographies of the various members of his family, entitled 'Family Biographies' (Jiazhuan 家傳):

To write a biography of my great-great-grandfather is like restoring to the moon its fullness after an eclipse, for what was once a lacunae can now be viewed; writing a biography of my grandfather, on the other hand, is akin to writing a reflection, for having limned a half-likeness, the whole may be guessed; writing a biography of my father is like the huge fish caught in a fisherman's net of which even the smallest details can be observed. Being myself quite without talent I am unable to invent the physiognomies of my late ancestors and can but hope that I do not here lose too much of their original faces, their true faces, even a half glimpse of how they looked when they laughed or as they wept. 'When the leper woman gives birth to a child in the dead of the night, she rushes to fetch a torch and examine it, trembling with terror lest it look like herself. ${ }^{, 13}$ Fortunately, my ancestors were not lepers. As I cannot hope to fully capture a true likeness of their physiognomies in my biographies of them, in dead of night I rush to fetch a torch and examine them, trembling with terror both lest they look like me and lest they do not, for either outcome would prove equally mortifying. ${ }^{14}$

What is interesting here and elsewhere in his writings is the extent to which Zhang Dai emphasizes the visual appearance of his ancestors when speaking about the writing of their biographies, and the importance he accords verisimilitude. His vocabulary is that of the portrait painter: he speaks of 'writing a reflection' (xiezhao 鴧照), of 'limn[ing] a half-likeness' (xiao qi ban 肖其半), of 'fully captur[ing] a true likeness' (kuxiao 酷肖) of the 'original faces' (benmian 本面) or 'true faces' (zhenmian 真面) of his biographical subjects. His friendship with Chen Hongshou, in particular, would have meant that he was intimately familiar with developments in the art of portraiture during this period. ${ }^{15}$ As an occasional painter himself, whose portfolio included at least one self-portrait,

\footnotetext{
${ }^{13}$ This is a quotation of a passage from the 'Heaven and Earth' chapter of the Zhuangzi, for which, see Watson (1968: 140).

14 'Jia zhuan' (Zhang Dai 1985: 154-55).

${ }^{15}$ Zhang Dai also knew the painter Zeng Jing 曾鯨 (1568-1650), a man who James Cahill believes to have been the 'leading portrait specialist of the time.' Cahill cites the entry on him in a Qing dynasty work on the painting of the Ming: '.. he painted portraits that looked like reflections of the models in the mirror, capturing wonderfully their spirit and feelings. His coloring was deeply rich. The eye-pupils were dotted for effects of animation. Although [the faces] were only on paper and silk, they would glare and gaze, knit their brows or smile, in a manner alarmingly like real people ... When one stood looking at such a face, one forgot both the man and oneself in a moment of spiritual comprehension.' (Cahill 1982: 116). As Cahill suggests, Zeng's practice as a painter may have been influenced by Western painting techniques, examples of which he had in all likelihood much opportunity to observe in both Fujian Province and, later, in Nanjing. There are two mentions of Zeng Jing in Zhang Dai's Dream Memories of Taoan. In the first of these, Zhang Dai tells of meeting up with Zeng (and seven others, including Chen Hongshou) whilst taking a tour around West Lake on Wang Ruqian's 汪汝謙 barge, called his Untethered Garden (Buxiyuan 不系園), on which, see Cao Shujuan (2006: 197-235). On this occasion, whilst others sang, danced, and played various musical instruments, each according to his or her particular talents, Zeng Jing, we are told, ‘wrote a reflection' (xiezhao 鴧照). For this item, see Zhang Dai (2001: 58-59).
} 
only the colophon to which has survived, ${ }^{16}$ Zhang Dai would have had a working knowledge of both the method and the vocabulary of portrait painting, as well as easy recourse to the burgeoning production of illustrated books (as a young man he had a particular affection for illustrations of the characters from the novel Shuihu zhuan 水游傳 [Water Margin]), and painting manuals.

At the very end of his long life, with his book Portraits, Zhang Dai sought to bring to a conclusion a long-standing project to collect and publish (and thus, he believed, best ensure the immortality of) whatever available portraits existed of the worthies of his home province of Zhejiang, including those of a number of his own friends and relatives. The book was completed sometime around 1680 and includes the portraits of some 109 people, unevenly distributed between the 'Three Eternals': 'Virtue' (lide立德) (eightyseven portraits), 'Deed' (ligong 立功) (nine portraits), and 'Word' (liyan 立言) (thirteen portraits). Within each of these categories, the people commemorated were further divided into various subcategories. ${ }^{17}$ And if the collection reveals an overwhelming bias for the first of the categories, it will occasion little surprise that the work embodies also an extreme gender imbalance-it includes the portraits of only six women, all of whom are found in the 'Virtue' category, and two of whom are included in the mixed subcategory of the 'Filial Martyrs' (xiaolie 孝烈), the other four found in that exclusive category of female biography of those who were 'Martyrs in Defence of their Chastity' (jielie 節烈). In each case, the portrait ( $t u$ 圖) was carried on the recto of the page, whilst the verso provided a short biography, accompanied by a eulogy or poetic panegyric (zan 贊). ${ }^{18}$ All the portraits contained in the work are posthumous in that they are of people who had already died by the time the portrait was collected for the purpose of inclusion in the book.

\footnotetext{
${ }^{16}$ This colophon reads: 'My pursuit of fame all come to nought,/ My quest for fortune proven but a dream./ The fear of pain means no loyal minister I,/ And yet too heavy the hoe for me to ply./ Twenty year's writing fit only to seal my sauce vats,/ What use, you say, a man such as I?' ('Ziti xiaoxiang' 自題 小象 [Inscribed on a Small Self-Portrait]) (Zhang Dai 1985: 246).

${ }^{17}$ The 'Virtue' category has twelve subcategories ('Neo-Confucian Masters' (lixue 理學), 'Martyrs for Loyalty’ (zhonglie 忠烈), 'Men of Integrity’ (zhongjie 忠節), 'Loyal Remonstrancers' (zhongjian 忠諫), 'Filial Martyrs' (xiaolie 孝烈), 'The Righteous Martyrs' (yilie 義烈), 'Martyrs in Defence of their Chastity' (jielie 節烈), 'The Un-corrupt' (qingjie 清介), 'The Upright' (gangzheng 剛正), 'The Moral' (shengde 盛德), 'The Recluses' (yindun 鿵遁), and 'The Filial' (shengxiao 生孝)); both the 'Deed' ('Honoured Service' (xunye 熏業), 'Ministerial Service' (xiangye 相業), and 'Service of Merit' (gongye 功業)) and the 'Word' ('Literary Arts' (wenxue 文學), 'Wide Learning' (boxue 博學), and 'Fine Arts' (huayi 畫㙯)) categories each have three subcategories.

${ }^{18}$ In the case of the illustrations that accompany this paper, I have juxtaposed the image (recto) and text (verso). To 'read' ( $d u$ 讀) both of these, the reader would normally need to turn the page.
} 
It would seem that by the time the book was finally ready for publication, Zhang Dai too had either died or was on his deathbed. His 'Preface' to the book, translated in full below, is dated to the year 1680, its use of a deliberately archaic means of notating this date, and his failure also to provide reference to the relevant reign title (the year in question represented the $19^{\text {th }}$ year of the reign of the Kangxi emperor), expresing something of a double disavowal of the ruling house. Perhaps half the complete work had been printed by 1689 but, the carved woodblocks having been stored away, a full publication had to wait another two hundred years, to 1888 , the Wuzi year, the $14^{\text {th }}$ year of the reign of the Guangxu emperor.

In this 'Preface,' Zhang Dai is explicit about both the process undertaken in compiling the work, and its intended ritualistic and didactic purposes:

\section{'Preface,' Portraits of the Eminent Worthies of Zhejiang During the Ming Dynasty Whose Lives Embodied the Three Eternals}

In distant antiquity, we are told in 'The Charge to Yue' (Yue ming 說命), Di 帝 appeared to King Wuding 武丁 in a dream to grant him knowledge of a good assistant. The king then proceeded to describe this man in detail so that he could be searched for throughout the empire by means of a portrait (tuxiang 圖像). ${ }^{19}$ Again, when Emperor Huan of the Han summoned Jiang Gong 姜胠 and he did not respond to the summons, the emperor ordered a portrait (xiang 像) of him to be made by his court painting masters. ${ }^{20}$ Such, then, was the sincerity of the admiration on the part of the ancients for men of integrity. When their ardent wish to see the faces (mian 面) of such men in person proved impossible, they would have portraits of them made in order that they could nonetheless gaze upon their visage (zhanyang 瞻仰).

This remained the case down through the ages and is the explanation for such instances of the commissioning of portraits as those of Ying Isle 瀛洲, Qilin Gallery 麒麟閣, Cloud Terrace 雲臺, Gallery that Skims the Smoke-like Clouds 凌煙閣, even 'The Nine Old Men of Fragrant Hill' (香山九老), the 'Elegant gathering at the Western Garden'西園雅 集, and the lustration ceremony at Orchid Pavilion 蘭亭修裙, all of these events having been commemorated in paintings so that a semblance of the men involved could be transmitted to later generations (zhenzhong tuxing yi chuan houshi 珍重圖形以傳後世). In this way, and joyously, a single glance at the manner and appearance (yijian q $i$ zhuang 一 見其狀) of the worthies of the past on the part of those who come later would immediately be enough to overcome that regret that Emperor Wu of the Han Dynasty once experienced at not having been born in the same age as the poet Sima Xiangru 司馬 相如.

\footnotetext{
${ }^{19}$ For a translation (and discussion in the light of traditional understandings) of this section of the Shang $s h u$ 尚書 [Book of Documents], see Legge (1960: 3, 250-51): 'The king on this made a writing, and informed them saying, "As it is mine to secure what is right in the four quarters of the empire, I have been afraid that my virtue is not equal to that of my predecessors, and therefore have not spoken. But while I was respectfully and silently thinking of the right way, I dreamt that God gave me a good assistant, who should speak for me." He then minutely described the appearance of the person, and caused search to be made for him by means of a figure throughout the empire. Yue, a builder in the country of Fuyan, was found like' (Romanisation altered).

${ }^{20}$ For which, see 'The Collected Biographies of Zhou, Huang, Xu, Jiang, and Shentu' (Zhou Huang Xu Jiang Shentu liezhuan周黄徐姜申屠列傳) in Hou Han shu (1965: 3, 1749-50).
} 
In my youth I was most fond of gathering together as many anecdotes of my dynasty as I could find and retelling them. ${ }^{21}$ In the course of my work I discovered that many were the elders of my native province of Zhejiang who had earned immortality as a result of their virtue, their deeds, and their words. As my admiration for these personages grew apace, I found myself attempting to envisage their appearance and bearing (zhuixiang yirong 追想儀容). And so, with Xu Qin 徐沁 as my collaborator, ${ }^{22}$ we set off going doorto-door begging earnestly for whatever posthumous portraits (yixiang 遺像) existed of these figures, in order that we might gather them together as a collection and render them permanent by means of jujube and pear. In this way, these portraits might then hang on the walls of school halls, to be worshiped in front of, at dawn and at dusk, or one may encounter them the moment one opens up this present book.

For my own part, whenever I see a portrait of some master or other of moral philosophy, I am overcome by that same sense of shame one experiences whenever one starts at the shadows whilst all the while lying safely beneath one's blankets; when I see the portrait of someone noted for their loyalty or their filial piety, I reflect shamefully on my own failure in these respects; at the sight of those celebrated for their integrity and steadfastness of purpose, I feel contempt at my own continued entanglement with the temptations of fame and fortune; the sight of the prose masters of the past sees me overcome by the extent to which my own reading of the classics of poetry and history has been in vain; when I see the portraits of those who have given meritorious service to the empire, I regret intensely that I, for one, have allowed the locusts to strip bare the fields of grain; and when confronted with the portraits of men skilled in the arts, I am mortified by my own complete failure in this respect as well. Over time this sense of shame and regret has served to shock me out of the torpor of spirit into which I had sunk, to replace my abject fear with an heroic air, rousing me to act whenever I encounter such portraits, day or night, and to the extent that 'unconsciously the hands begin to move and the feet to dance.'23

Having myself experienced the misfortune of living through an age when time itself changed (yu buxing zao shibian 予不幸遭時變) and in accordance with the instructions of my ancestors, I have sought to preserve my status as a teacher of men and, out of my admiration for the worthies of the past but knowing only their names and having no portraits (xiang 像) of them to gaze upon, I have embarked upon the quest with my likeminded collaborator of going door-to-door in search of such portraits. So sincere have proven the descendants of these worthies that with immediate generosity they have responded to our quest, on some occasions kindly dispatching a portrait to us from a thousand $l i$ away, on other occasions spending several years hunting for such pictures ( $t u$ 圖) without success. As the many months have gone by, we have brought this work to completion between its covers, this surely being no small feat of hand and foot!

As to whether this book and the portraits it contains will be handed down on into the future without end and whether the people that it commemorates will thus become eternal (buxiu 不朽), this will depend upon those in later generations who care to take up this book and to read it.

\footnotetext{
${ }^{21}$ This is a reference to Zhang Dai's earlier excursion into this form of didactic biography, his Gujin yilie zhuan [Biographies of the Martyrs Ancient and Modern] mentioned earlier in my paper, which he had worked on in the mid 1620s. In the preface to this work, Zhang Dai recalls how emotionally involved he would become when reading the tales of heroes of the past, real or imaginary, to the extent to which at times he would have to stop reading. 'Why did I care about their fates so intensely?,' Zhang Dai asks rhetorically, 'It was for no other reason than the provocation (tiaoji 挑激) of these two words: loyalty and righteousness (zhong yi liang zi 忠義兩字), for which see Zhang Dai (1991: 409).

${ }^{22} \mathrm{Xu}$ Qin, himself an artist of some note, was a grandson of the eccentric painter, calligrapher, essayist and playwright Xu Wei 徐渭 (1521-1593), also a native of Shanyin (present-day Shaoxing) and Zhang Dai's most important literary model. A portrait of Xu Wei is included in the work being discussed, for which, see Figure 6.

${ }^{23}$ Zhang Dai here cites a line from 'The Grand Preface' (大序) of the Shi jing 詩經 [Book of Songs], for which, see Legge (1960: 4: 34).
} 
This preface written by the Old Man of Ancient Sword [in Sichuan] in the mid-autumn of the Shangzhang Tuntan 上章涒灘 year [1680].

Here in this 'Preface,' perhaps the last extant thing that he wrote after almost four painful decades of attempting to capture in words the lost world of his misspent youth, Zhang Dai employs a complicated and sophisticated version of the biographical taxonomy of the Three Eternals both in order to confess his own failings of one sort or another, and in the hope that the images he and his associate had gathered together, some examples of which are given here (Figures 1-10), might serve to rouse others to strive to embody in their lives the pursuit of immortality in these terms.

All ten of the examples chosen to accompany this essay show men dressed, as only to be expected, in the loose-necked robes with wide sleeves typical of the Ming dynasty. Two men, Zhang Yuanbian 張元泫 (1538-1588), Zhang Dai’s great-grandfather (Figure 4), and his friend Qi Biaojia (Figure 7), wear on their chests the insignia appropriate to their civil service rank ( $p u z i$ 補子), the peacock (third rank) and the crane (first rank) respectively. Again as only to be expected, all men wear hats of various kinds, in accordance with their status: whereas three men (Figures 1, 3, and 5) wear formal Coronet Ridges (liangguan 梁冠) for formal court occasions, two (Figures 4 and 7) wear the Black Gauze Magistrates Hat (wusha mao 鳥紗帽) so typical of office holders of this period, one (Figure 6) wears the Four Quarters Pacified Hat (sifang pingding jin 四方平 定巾), ${ }^{24}$ and the others (Figures 2, 8, 9, and 10) wear varieties of informal headkerchief. $^{25}$ Figures 1, 2, and 5, again, are all holding in front of them their court Tablets ( $h u$ 笏).With the exception of the portrait of Wang Yangming (Figure 1), who is depicted looking off towards his left, all the other ten men are shown either facing the viewer directly or casting their eyes slightly to their right. Although obviously produced in keeping with the techniques illustrated in the various painting manuals available at the time, with the physiognomic implications of various types of features, each portrait nonetheless manages to convey something distinctive about the individual depicted. They stare out at us, their gaze as if cast beyond us to future generations.

\footnotetext{
${ }^{24}$ This particular hat grew higher and higher during the Ming, to the extent that it was said to resemble a bookcase, for which, see Zhou (1984: 383).

${ }^{25}$ A number of the illustrations of various Ming dynasty styles of headwear given in Zhou (1984: 393-94) are taken from Zhang Dai's Portraits.
} 

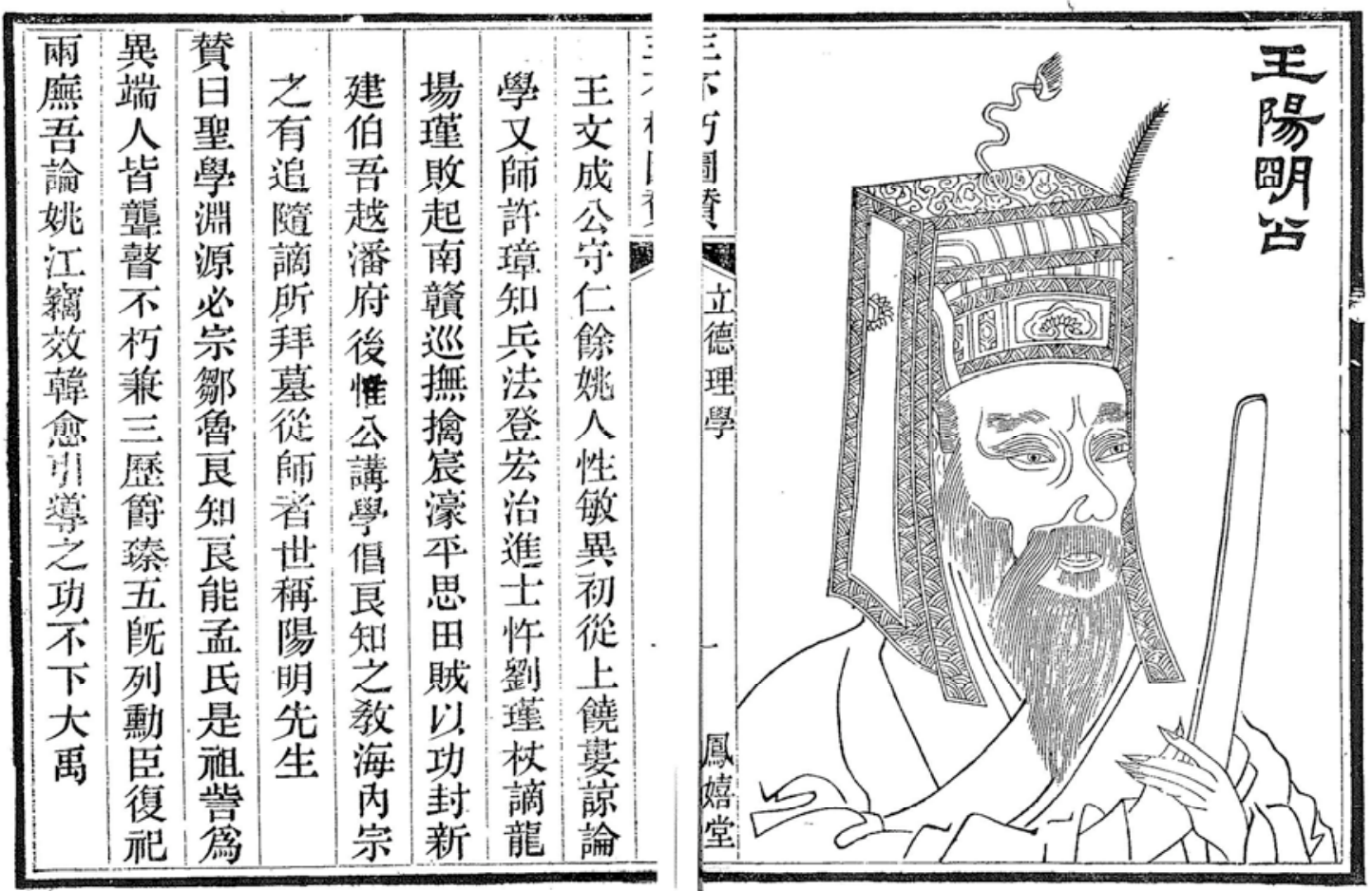

Figure 1: Wang Yangming (1472-1529)
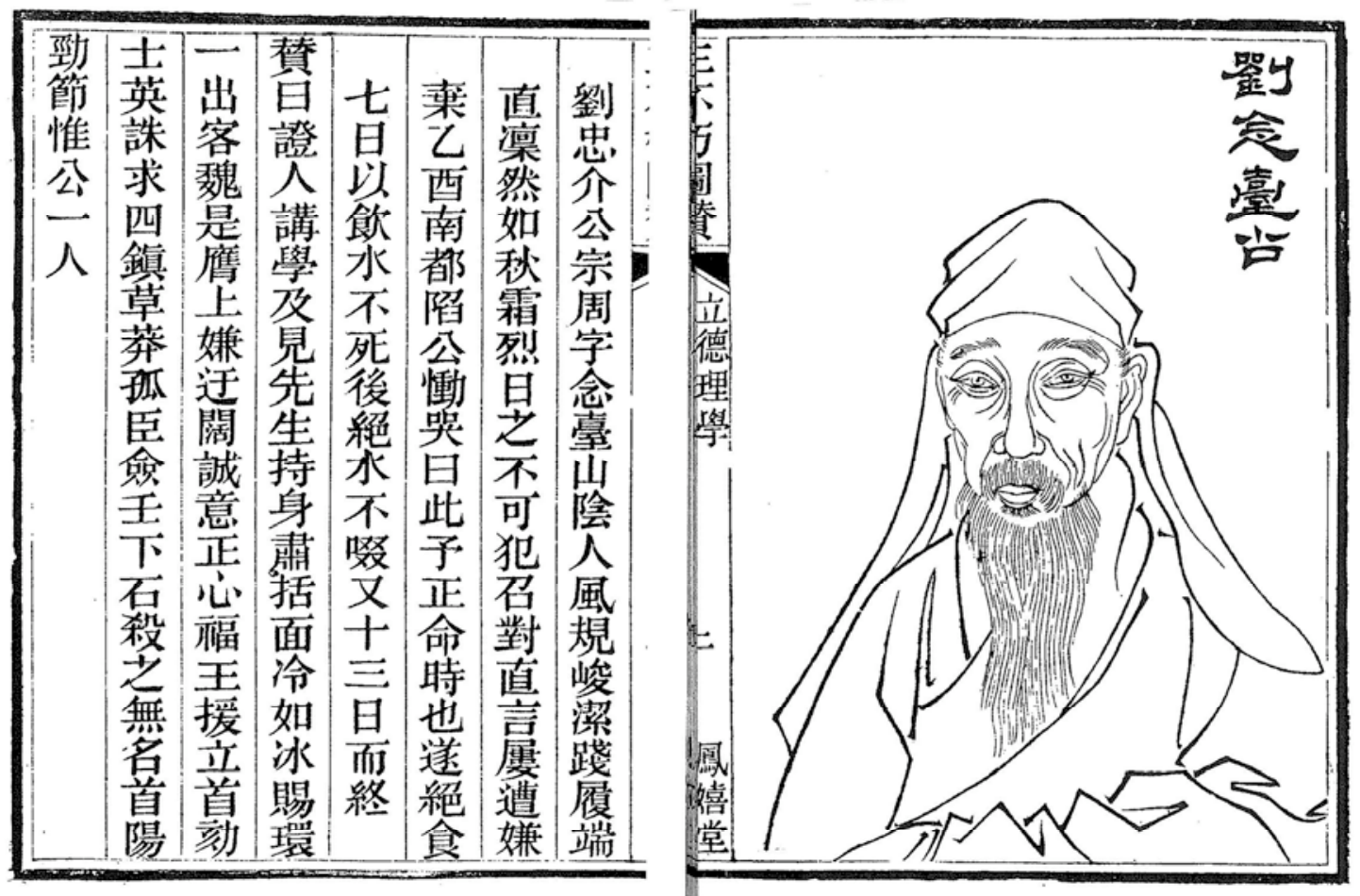

Figure 2: Liu Zongyuan (1578-1645) 

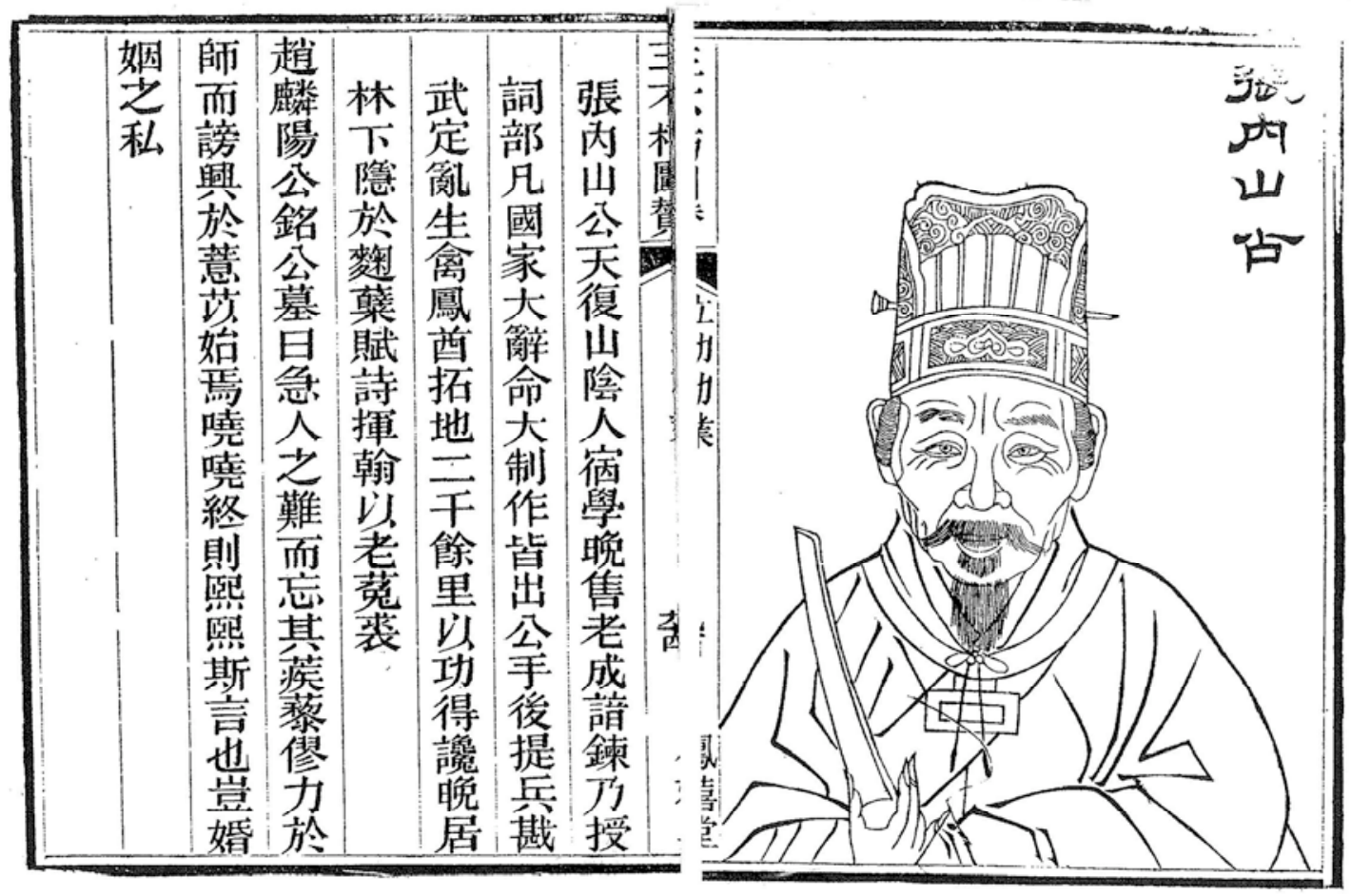

Figure 3: Zhang Tianfu (1513-1573)—Zhang Dai's Great-great-grandfather
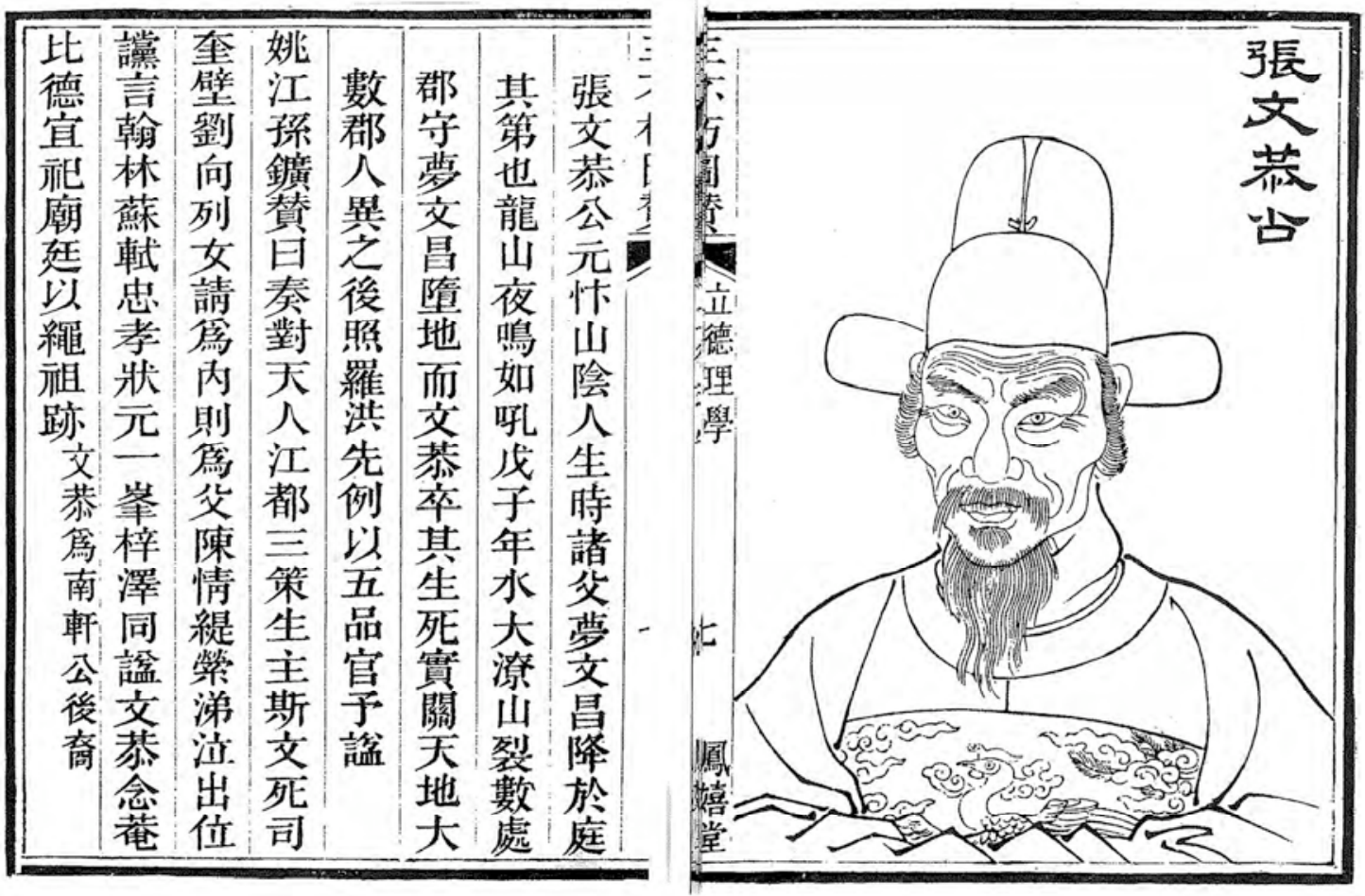

Figure 4: Zhang Yuanbian (1538-1588)—Zhang Dai's Great-grandfather 

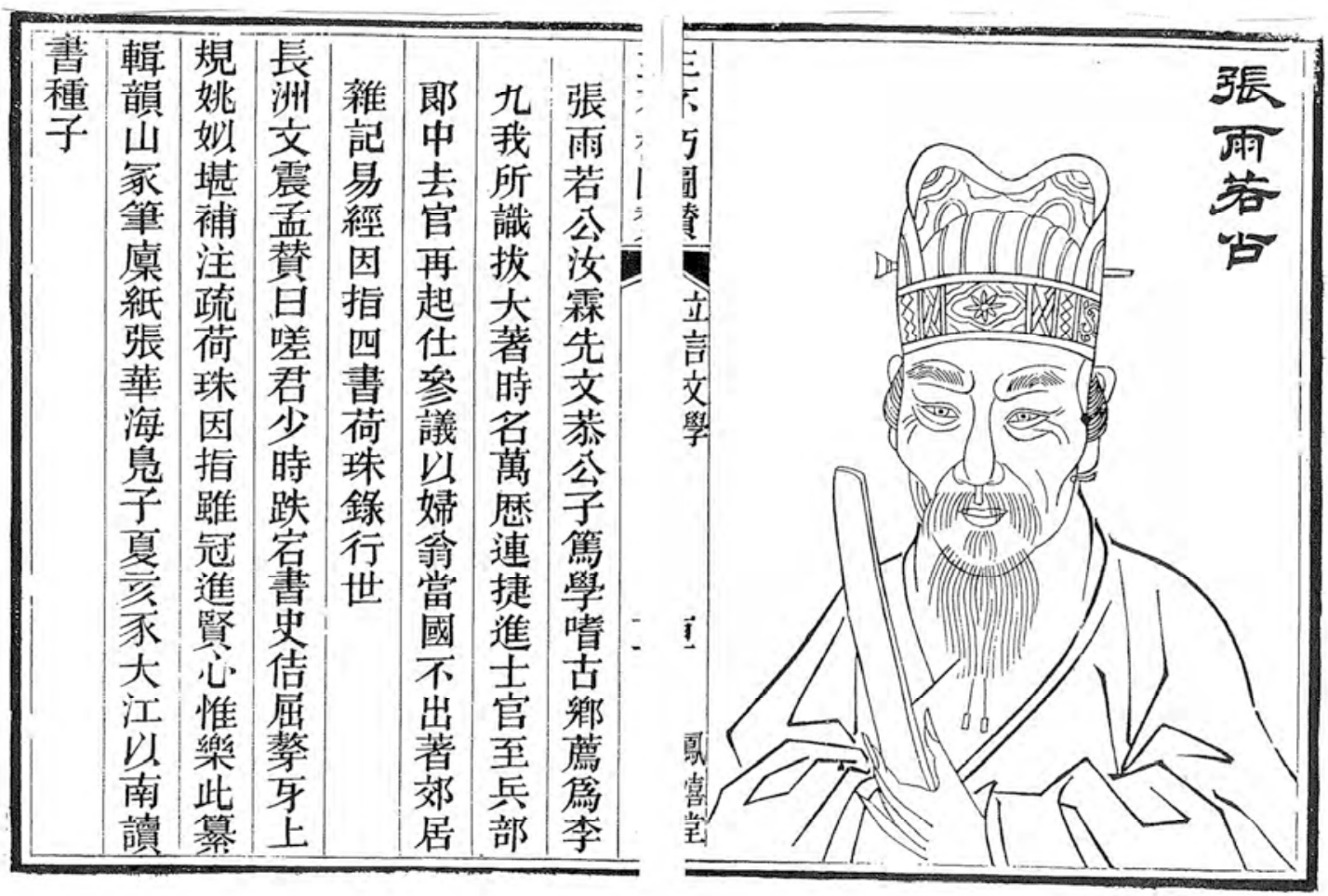

Figure 5: Zhang Yuruo (d. 1625)—Zhang Dai's Grandfather
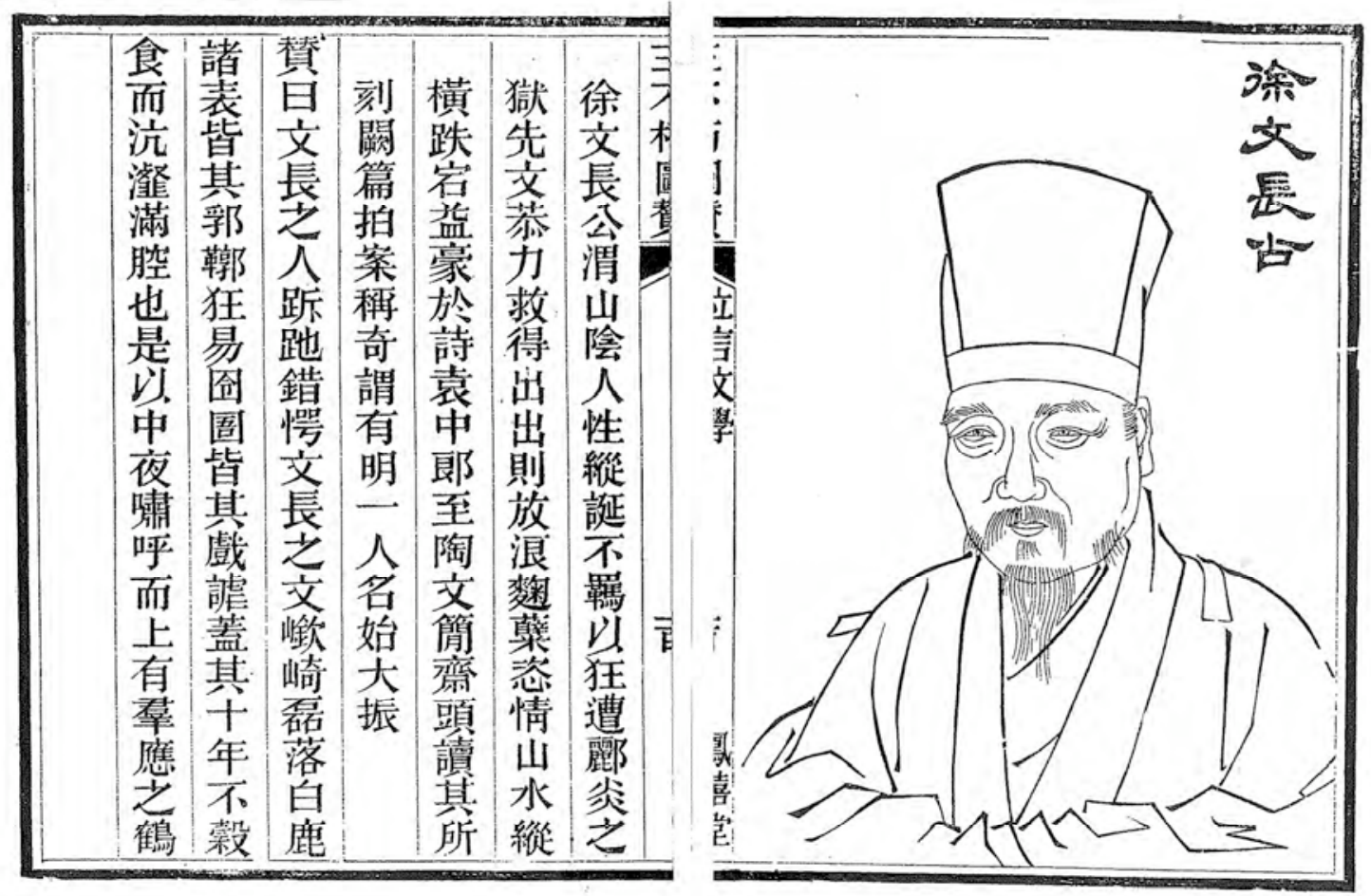

Figure 6: Xu Wei (1521-1593)—Xu Qin's Grandfather 


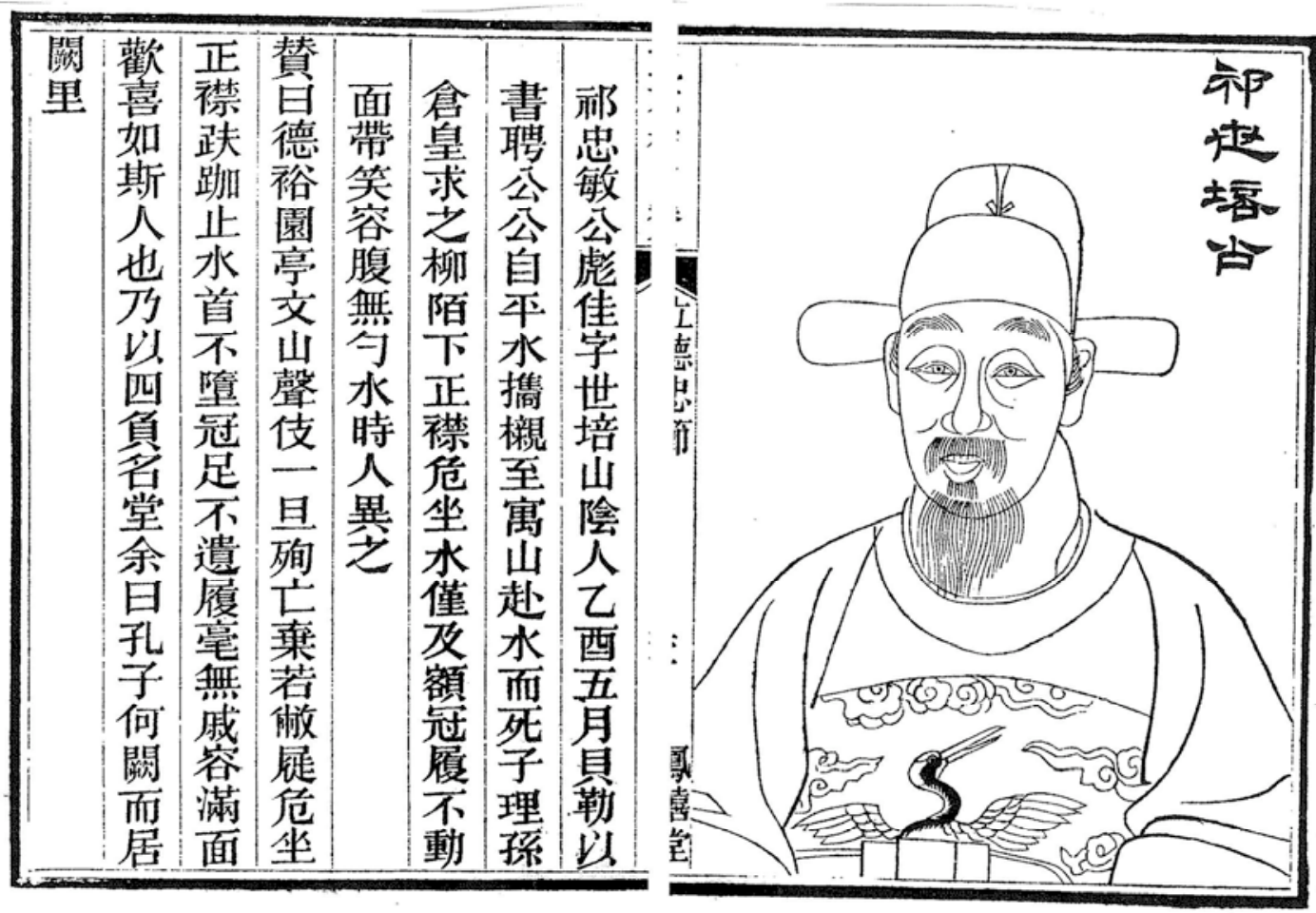

Figure 7: Qi Biaojia (1602-1645)

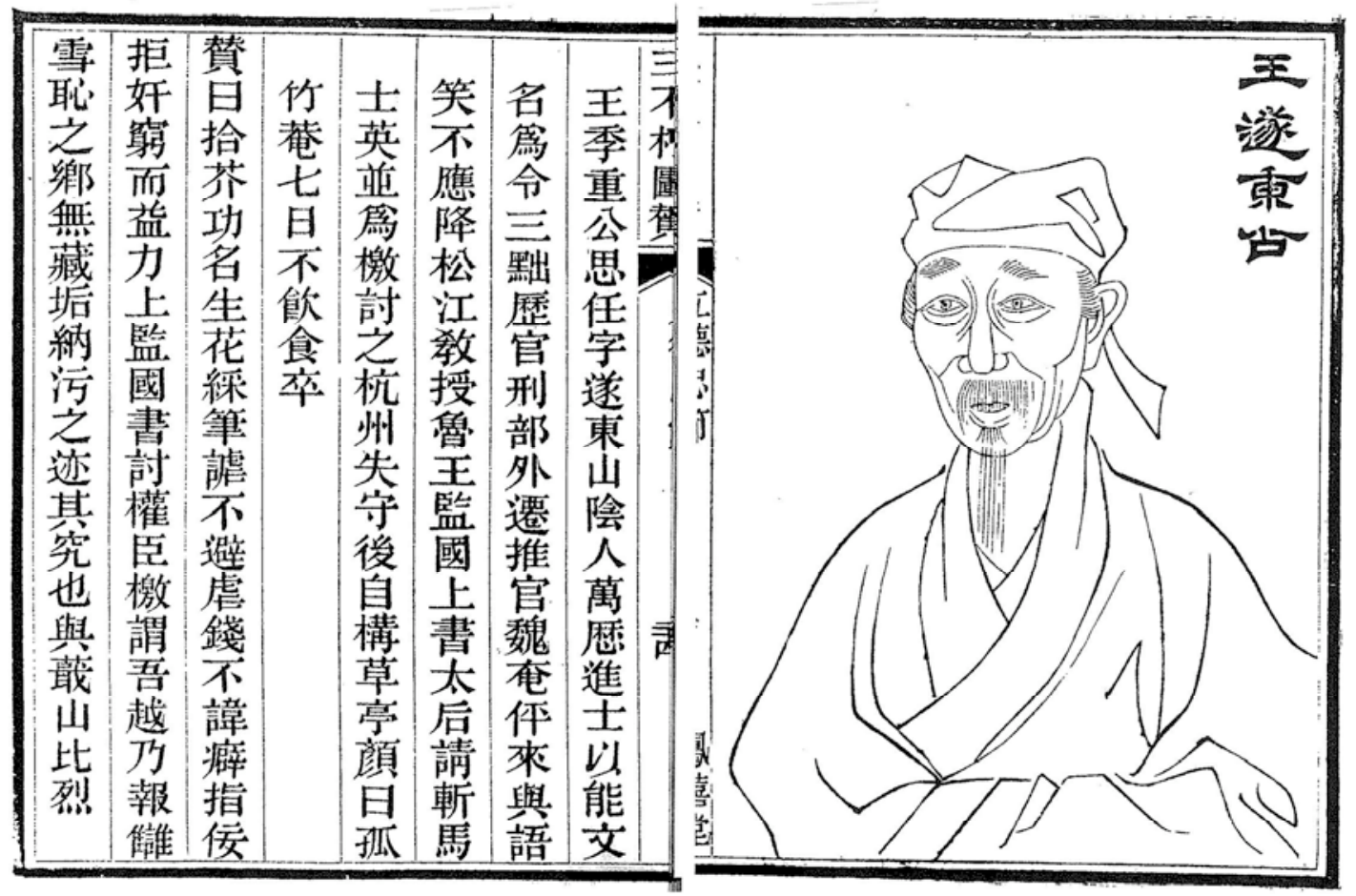

Figure 8: Wang Siren (1575-1646) 

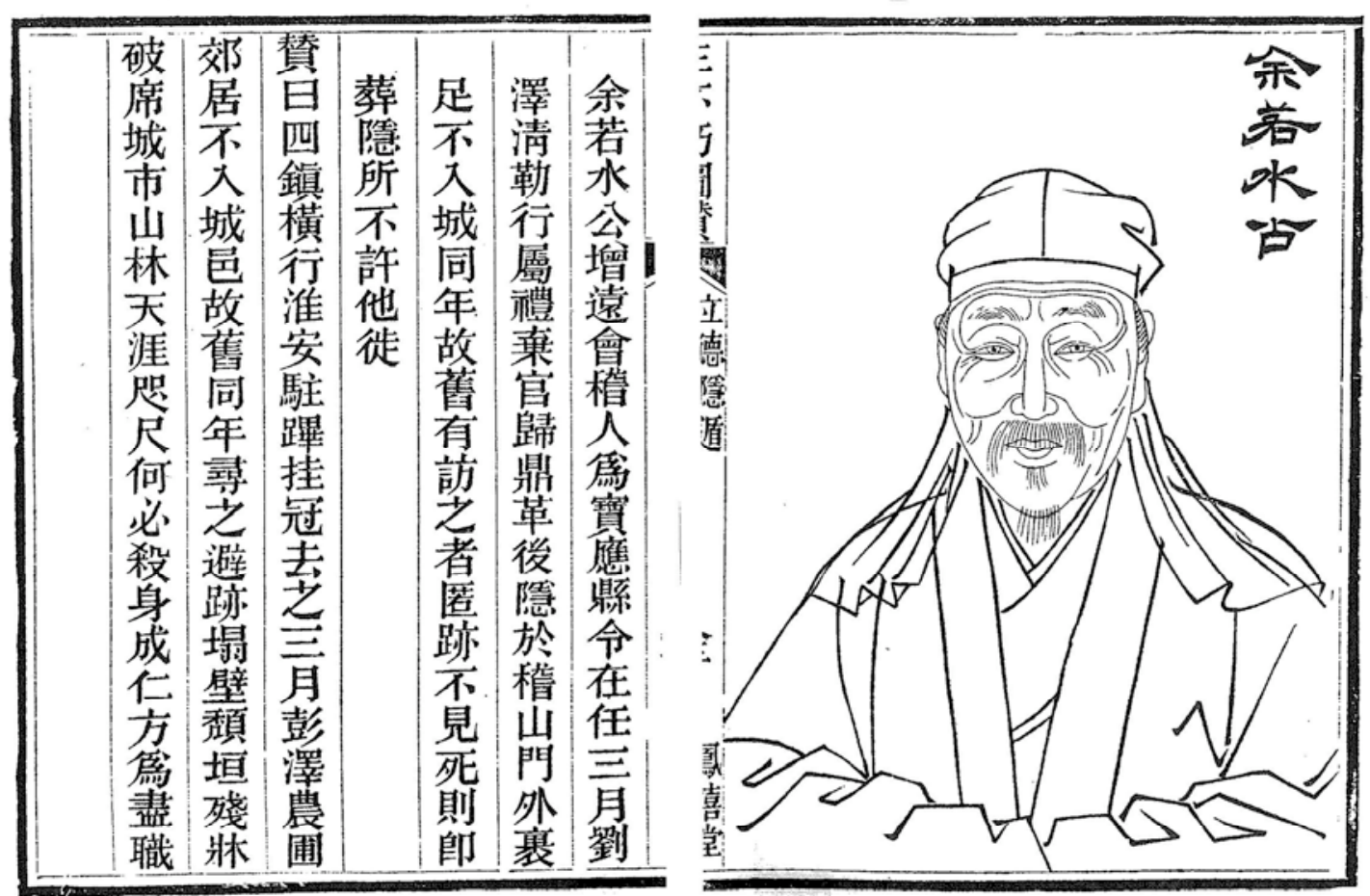

Figure 9: Yu Zengyuan (d. 1670)
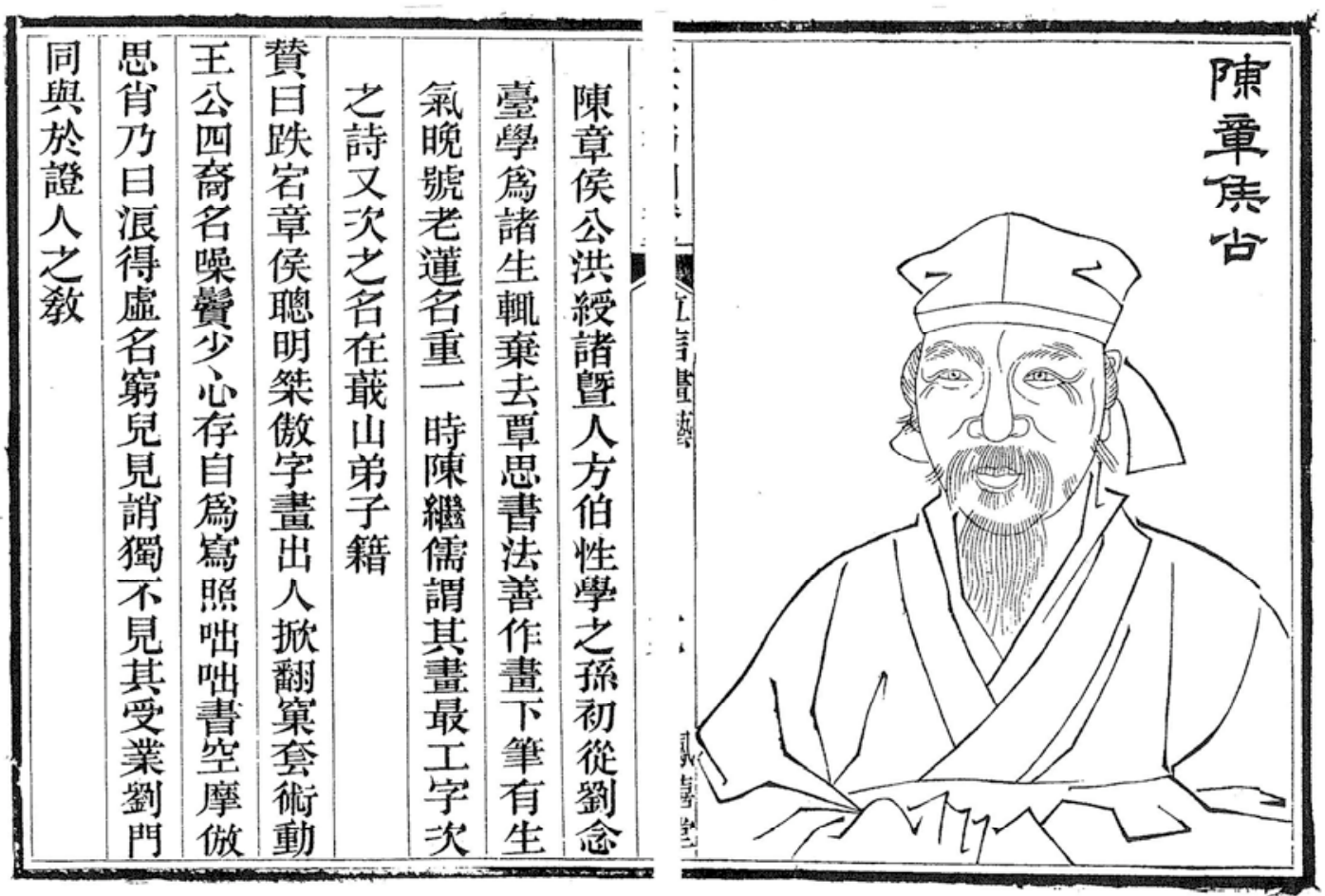

Figure 10: Chen Hongshou (1598-1652) 
The first two portraits are of men who, appropriately, represent the beginning and end of the particular strand of Neo-Confucian scholarship within which earlier generations of Zhang Dai's own family had worked with some considerable success and which was centred in Zhejiang: Wang Yangming 王陽明 (1472-1529) and Liu Zongzhou 劉宗周 (1578-1645), both placed within the 'Virtue: Neo-Confucian Masters' category (Figures 1 and 2). In the case of the second of these figures, in the short attached biography, Zhang Dai, who must have known Liu Zongzhou personally, dwells on the manner of Liu's death: 'And when in the Yiyou year [1645] the Southern Capital fell, the Master wept with grief, saying "My hour has come," whereupon he fasted for seven days. But as he had continued to drink water and thus lived on, he then refused to drink as well. He died after another thirteen days had past.'

In the case of the portraits of his own ancestors (Figures 3-5), of his great-greatgrandfather, Zhang Tianfu 張天復 (1513-1573) ('Deed: Service of Merit'), greatgrandfather, Zhang Yuanbian ('Virtue: Neo-Confucian Masters'), and grandfather, Zhang Yuruo 張雨若 (d. 1625) ('Word: Literary Arts'), Zhang Dai, in his short biographies, tells of these men's official service, giving only the occasional and sparing detail of their lives, but in his panegyric is, in all three cases, happy to cite the words of others about these men.

The portrait of his collaborator Xu Qin's ancestor, his grandfather Xu Wei (Figure 6), is also placed in the 'Word: Literary Arts' category. Zhang Dai's short attached biography alludes to some of difficulties this man experienced in his life (his murder of his wife, his imprisonment, his addiction to alcohol, his repeated attempts at suicide, his insanity), mentions the efforts of his own great-grandfather to have Xu Wei released from incarceration, and the posthumous recognition of Xu Wei's greatness as a poet by Yuan Hongdao 袁宏道 (1568-1610) when in 1597 he came across a collection of his poems sitting on the bookshelf in Shanyin of another man commemorated in his book, the scholar Tao Wangling 陶望齡 (b. 1562). One of Zhang Dai's earliest literary efforts had been an anthology of Xu Wei's uncollected writings; Zhang Dai had been told by a friend that he was himself a reincarnation of $\mathrm{Xu}$ Wei, and, poetically, he struggled for most of his life to rid himself of the influence of this earlier master. 
In the short biographies attached to the portraits of three of Zhang Dai's closest friends (Figures 7-9), Qi Biaojia ('Virtue: Men of Integrity'), Wang Siren (also 'Virtue: Men of Integrity'), and Yu Ruoshui 余增遠 (d. 1670) ('Virtue: The Recluses'), he again dwells upon the manner of these men's deaths: in the case of the first two men, at their own hands, Qi Biaojia by drowning and Wang Siren by starvation. In understanding the particular significance to Zhang Dai of Yu Zengyuan's death, the third of his friends commemorated here, much delayed and of natural causes, we have recourse, by way of comparison, to a fuller biography of the man that Zhang Dai included in his collected works, as given below: ${ }^{26}$

Biography of Master Yu Ruoshui

Master Yu Ruoshui 余若水 was given the personal name Zengyuan 增元 and was a Metropolitan Graduate of the Guiwei year of the reign of the Chongzhen emperor of the Ming dynasty [1643]. His elder brother, Master Yu Wuzhen 余武貞, with the personal name Huang 煌, had for his part taken first place in the Palace Examinations of the Yichou year of the reign of the preceding Tianqi emperor [1625], before taking up office as a Senior Compiler in the Hanlin Academy. Ruoshui's first official posting was as Magistrate of Baoying County in Huaian Prefecture. At the time, the Earl of Dongping, Liu Zeqing, was in charge of the military affairs of the Huaian area and insisted that all the local magistrates treat him as their superior. ${ }^{27}$ Unbowed by such intimidation, Ruoshui hung up his official's cap and returned home, having served for little more than a month.

In the Bingxu year [1646], when the troops of the Great Qing dynasty crossed the Yangtze River, Master Wuzhen drowned himself beneath Eastern Bridge. Ruoshui, mourning the destruction of his state and grieving over the early death of his wise brother, faced the river and wailed, swearing never to cross it again. From this time onwards, he never again entered the towns and marketplaces of the empire.

\begin{abstract}
Although Ruoshui had become a Metropolitan Graduate, his family remained extremely poor. He lived in a modest house of only three rooms, and this he shared with the wind and the rain, the birds and the rats. He leased two $m u$ of land beside his house and there he led his family personally to plough and till the fields, trying to live off the produce of their own labours but often going without a meal. His wife and children were content with their lot; neither did they ever show the slightest sign of resentment at their fate. All the local Senior Subalterns, in admiration for Ruoshui's sense of righteousness, would pay their calls to enquire after him, even those he had had little to do with in the past would pay homage at his door before passing on their way.
\end{abstract}

The Intendant of the Shaoxing Circuit at the time, Shen Jinglan 沈静瀾, happened to be to be a fellow examination candidate of Ruoshui's, and trusting to their earlier friendship, he would assiduously invite Ruoshui to join him. Such invitations, however,

\footnotetext{
${ }^{26}$ Zhang Dai's collected works (1991) contains also a longer biography of Wang Siren.

${ }^{27}$ For a brief biography of Liu Zeqing 劉澤清 (d. 1648), see Hummel (1943: 531-32). Struve (1984: 28) discusses Liu Zeqing's fraught relationship with the civil bureaucracy. Labelling him a 'homicidal militarist,' she cites an address he made to the Emperor: 'The world of the [Ming] ancestors has been completely ruined by white-faced schoolboys. This whole bunch should be tied up in a high tower until after I have beaten the rebels. Then they could be taken and out to work dusting and cleaning, perhaps to earn some favour that way. Today I request terminating the civil service examinations to facilitate matters' (1984: 22).
} 
Ruoshui would always refuse, with the excuse that he was unwell. On one such occasion, Shen Jinglan went himself to pay a call on Ruoshui in his sickbed, and when he entered his room he caught sight of Ruoshui lying upon a rope bed. The roof above the bed leaked and the small table that stood beside it was missing a leg. Broken tiles lay strewn everywhere. Hearing that a guest had arrived, Ruoshui started for the back door. Having anticipated that this would be the case, Shen Jinglan had asked four or five other fellow examination candidates of Ruoshui's to accompany him on his visit. When they saw that Ruoshui was about to flee from his bed to hide, these gentlemen all rushed forward to check him, saying: 'Ruoshui! Life, by necessity, involves friendships and relationships. Why do you seek to avoid them so much?' To this Ruoshui replied: 'It is not that I wish to crow over my moral superiority for having retreated from the world, it is just that I believe my allotment of happiness to be small and that I am myself ill-suited to accommodating myself with the ways of the world. I am content with my lot in life and will be quite satisfied if I can hide away from the world and end my days as a peasant. By turning up here unexpectedly today, you gentlemen do no more than bring attention to me and I run the risk of becoming famous for trying to avoid fame, this not being at all what I desire.' His guests, however, spread the rushes and took their seats, as their host went over to the corner of the wall to put something on the boil. When the guests went over to take a look at what he was doing, they caught sight of a chipped pot sitting upon a tile brazier, the rice it contained not yet cooked. Frayed and worn, a coarse linen gown had been erected to afford some protection from the elements, reminding his guests of the circumstances once experienced by Yuan Xian, the poorest of Confucius' disciples. ${ }^{28}$ Ruoshui owned nothing more than this.

One of the guests had brought with him a jar of wine and some cups and so he took them out and presented them to Ruoshui. Reluctantly Ruoshui drank a toast or two but drank no more even upon being pressed to do so. When the conversation turned to the affairs of the world, Ruoshui lowered his head as if he could not hear what was being said. When occasionally he was asked a question, he would respond with platitudes about the weather. Late in the afternoon, he took his leave from his guests and retired. When, the next day, his friends turned up with money and rice to give him, he repeatedly refused all they offered. This being the situation, the local Senior Subalterns displayed respect for his wishes and seldom dared to pay calls upon him.

For thirty-six long years he avoided the towns and marketplaces. In the Gengxu year [1670], without experiencing a day's illness, he died. He possessed nothing, and so his friends had to cobble together the money for his funeral. He had left instructions that he wished to be buried on Dingdou Tumulus at Yuanyin.

I, Zhang Dai, your unofficial historian, have this to say: 'To serve as minister is to be ready to lay down one's life for one's sovereign; to change one's allegiances is the

\footnotetext{
${ }^{28}$ See Lunyu XIV.i: 'Yuan Xian asked about shame. The Master said: "When the Way prevails in the state, serve it. To serve a state that has lost the Way-this is shameful indeed." "He who has shed ambition, boastfulness, resentment, and covetousness, has he achieved the fullness of humanity?" The Master said: "He has achieved something difficult; whether it is the fullness of humanity, I do not know" (Leys 1997: 66). See also the 'Giving Away A Throne' chapter of the Zhuangzi: 'Yuan Xian lived in the state of $\mathrm{Lu}$, in a tiny house that was hardly more than four walls. It was thatched with growing weeds, had a broken door made of woven brambles and branches of mulberry for the doorposts; jars with the bottoms out, hung with pieces of coarse cloth for protection from the weather, served as windows for its two rooms. The roof leaked and the floor was damp, but Yuan Xian sat up in dignified manner, played his lute, and sang. Zigong, wearing an inner robe of royal blue and an outer one of white, and riding in a grand carriage whose top was too tall to get through the entrance to the lane, came to call on Yuan Xian. Yuan Xian, wearing a bark cap and slippers with no heels, and carrying a goosefoot staff, came to the gate to greet him. "Goodness!" exclaimed Zigong. "What distress you are in, Sir!” Yuan Xian replied, "I have heard that if one lacks wealth, that is called poverty; and if one studies but cannot put into practice what he has learned, that is called distress. I am poor, but I am not in distress!" Zigong backed off a few paces with a look of embarrassment. Yuan Xian laughed and said, "To act out of worldly ambition, to band with others in cliquish friendships, to study in order to show off to others, to teach in order to please one's own pride, to mask one's evil deeds behind benevolence and righteousness, to deck oneself out with carriages and horses-I could never bear to do such things!"' (Watson 1968: 315-16; Romanisation altered).
} 
embodiment of disloyalty. To be roused by anger to become a martyr is to bring illustriousness to one's reputation for integrity. Righteousness serves to protect the will, wisdom to preserve the body. And so I say that it was enough that my friend Ruoshui sought reclusion by becoming a peasant, in the expectation that he would meet up with his sovereign again in the afterlife and thus bring no disgrace to his ancestors. Moreover, his display of integrity was such that others cannot aspire to it. His elder brother sought his death in the river, and this river Ruoshui vowed never again to cross. They died more than thirty years apart, but both may be accorded loyal ministers to the House of Zhao. Being content to be a peasant, wringing his wrists in despair all his life, alas, how difficult was Ruoshui's lot.' (Zhang Dai 1985: 189-90)

Yu Zengyuan's difficult lot, the decision he had made to live on beyond the end of his dynasty, was of course precisely the decision that Zhang Dai himself had made, and in both this biography and the shorter one attached to his portrait of his friend, dressed in the plain robes of a Ming commoner, Zhang Dai is also seeking to defend himself from accusations of a failure to live up to the appropriate moral expectations, accusations that, elsewhere, he levels against himself.

A further and final justification for the choices he made is found in an item from Zhang Dai's Dream Memories of Taoan, in relation to the first of his friends here commemorated, Qi Biaojia. For understandable reasons, it is an item of this book that seems to have been excised from the editions of this work that were published during the Qing dynasty:

Qi Shipei

In the 9th month of the Yiyou year [1645], during the autumn, observing that things were going daily from bad to worse, I took my leave of the court of the Prince of $\mathrm{Lu}^{29}$ and retired to live in the region of Shan. Fang Guoan ${ }^{30}$ proceeded to have ceremonial gifts sent to me with the request that I return to the court to participate in discussions about the military situation. At the same time, he ordered the local officials to pay calls upon me to bring pressure upon me to accept his invitation. I found that I had no alternative but to comply and so on the 11th day of the 1st month of the Bingxu year [1646], I set off by way of North Mountain, passing over Tang Garden Range and putting up at the post stations of Level Waters and Han Inn. At the time I was afflicted by an abscess on my back which caused me to groan with pain and kept me lying awake all night long upon my pillow. On one such occasion, I saw suddenly a black robed runner who presented me with a card upon which were inscribed the words:

'Qi Biaojia presents his respects!'

I arose in alarm, just in time to observe Shipei push open the door of a side chamber, dressed in robes and hat of purest white. Awestruck, I too followed him in and took a

\footnotetext{
${ }^{29}$ Zhu Yihai (1628-1662), thirteenth Prince of Lu. In 1645, in Shaoxing, the Prince of Lu became Regent. A short biography of this man may be found in Hummel (1943: 180-81); for a discussion of the messy politics of the Southern Ming, and the role of the Prince of Lu, see Struve (1984; 1988: 641-725).

${ }^{30}$ Fang Guoan (d. 1646) was a general of the Southern Ming period who served for a time under the Prince of $\mathrm{Lu}$. He was later to surrender to the Qing forces. For information on his activities, see Struve (1984).
} 
seat. Knowing in my dream that he was already dead, I said: 'Shipei, you have already made that ultimate sacrifice in loyalty to the state, and in doing so you have brought glory to all of our generation.'

At this, Shipei smiled wanly, hurrying to say: 'You, my good sir, should have fled for your life into retirement at a time such as this; what are you doing now, returning from your refuge?'

'I wish to support the Prince of Lu in his role as Regent,' I replied, going on to inform him of the circumstances of my return and of the decision that I had come to.

Shipei laughed: 'Whoever is going to let you do what you want to do, in any case? They have forced you out of retirement for no other reason than this; you just wait and see, before ten days are up, they will be exploiting you for military supplies.'

'But Fang Guoan has invited me to return with utmost sincerity-I'm sure that he doesn't intend to cheat me in this way' I objected.

To this, Shipei responded: 'You know yourself that now that things have reached their present pass, nobody can be master of their own fate and there is nothing that can be done. Just take a look at the stars.'

With this, he dragged me out of my seat and we descended the stairs to look towards the southwest. There in the distance we observed all the various stars, both large and small, dropping from the heavens like rain and crashing to the earth with an ear-splitting roar.

Shipei said: 'If the stars are thus, what can be done, what can we hope to do? Return to your mountain fast quickly, my old friend, even a master chess player such as yourself will sooner or later fall prey to the same trap as I did!'

He straightened up again and began to depart, but as he did so he stopped to whisper into my ear: 'Finish your Book of the Stone Casket.'

With elegance and dignity, he was gone, and all I could hear now was the barking of dogs, as the roar of leopards. I awoke with a start, the sweat dripping down my spine. Beyond my door I could hear the wail of the dogs, as if in continuation of the sounds I had heard in my dream. I kicked my son awake and told him of my dream.

On the next day, I arrived back at home. As it transpired, within ten days, my son Biao had been dragged off in chains and indeed we were forced to pay for military supplies. So sincere is the spirit of a loyal man, and so numinous had it proven. (Zhang Dai 2001: 143-44)

The disjunction between the criteria with which, at the very end of his life, Zhang Dai approached his biographical labours in the realms of the verbal and the pictorial is illustrated, perhaps, most starkly by the last portrait that he included in his book, in the category of 'Word: Fine Arts.' It is of his friend Chen Hongshou, the artist whose contributions to the developing sophistication of both the arts of portraiture and woodblock illustrations I began this paper discussing. Chen was of course another who had chosen to live on in the shadow of the collapse of his dynasty, losing himself in eccentricity, drunkenness and, assumed or otherwise, insanity. Zhang Dai choses to mention none of this in his short attached biography, but rather notes, firstly, that Chen 
was a disciple of Liu Zongzhou, thus serving to connect the end of his book with its beginning, before citing the assessment of the respective merits of his painting, his calligraphy, and his poetry once made by the great cultural arbiter of the age, Chen Jiru 陳繼需 (1558-1639). ${ }^{31}$ The portrait of Chen Hongshou included in Zhang Dai’s book

(Figure 10) reveals none of the agony and pain of Chen's own self-portraits, but shows rather an artist seemingly at peace with himself and assured of his place within the historiographical category within which his friend had placed him. Elsewhere, Zhang Dai had captured a somewhat more vivid, if less edifying, picture of his troubled friend.

\begin{abstract}
On the $3^{\text {rd }}$ day of the $8^{\text {th }}$ month of the Jimao year of the reign of the Chongzhen emperor [1639], I sat drinking with Zhang Rumou 張汝牟, the old Man of Southern Flowers and my grandfather's younger brother, in his lake barge. I had resolved to go home before the moon rose, but, most disappointed by my intension, Chen Hongshou sought to prevent me leaving: 'On such a fine night,' he said, 'why not lie here covered in blankets?' I had a servant go off to get a flagon or so of home-brew, and then summoned a little skiff to take us to Broken-Off Bridge, with Hongshou sitting there drinking on his own and becoming, soon enough, quite inebriated.
\end{abstract}

\begin{abstract}
As we passed besides Jade Lotus Pavilion, our friend Ding Shuqian 丁叔潜 called out to our boat from the northern shore of the lake, and produced some sweet tangerines from Tangxi, which we ate with great enjoyment. Hongshou was lying in the boat shouting away to his heart's content when a young woman on the shore had her serving boy approach us: 'Could you, my good sirs, take my good lady to Number One Bridge?' I obliged, and the young woman hopped aboard in delight, proving a most fetching figure, dressed in light breeches and delicately made-up. Hongshou tried to ply her with wine: 'And like Sister One Zhang in the Tang tale, are you game enough to take a drink with this bearded old man, I wonder?' Again with delight, she accepted a drink. We had our skiff rowed to Number One Bridge, by which time the $2^{\text {nd }}$ watch of the night had sounded, and our wine was finished. We asked her where she lived but all we got in reply was a laugh. Hongshou wanted to follow her home, but once she had disappeared past the Tomb of Yue Fei, he was unable to pursue her any further. ${ }^{32}$
\end{abstract}

For all the developments that had taken place in terms of the quest for verisimulitude in the fields of both portrait painting and biographical writing in the late Ming period, developments that had in one way or another been such a part of his life, in his very last work, rather than seeking to investigate the dimensions of individuality that he had once argued guaranteed a man immortality, Zhang Dai chose to engage in the sort of didactic biography characteristic of his his earliest work. For him, it was a return to an orthodox and conservative historiographical tradition. Furthermore, such was the veneration due the images ('to gaze upon their visage') of those figures that he now chose to commemorate, in the lingering shadow of the collapse of their world, that their

\footnotetext{
${ }^{31}$ On whom, see Hummel (1943: 83-84).

${ }^{32}$ See Zhang Dai (2001: 56-57).
} 
accompanying portraits reveal only the most muted and constrained attempt to 'capture a true likeness' of the kind that had so accuated much of his biographical practice.

On one level, this can be understood as being very much in keeping with Zhang Dai's particular bent of mind. He was a man who had spent much of his life seeking to take aspects from one domain of life, art and literature, and 'translating' them into other realms. Just as in his biographical writings he had employed the terminology of the painter, so too did he now introduce into the field of the portrait the hidebound categories of moralistic biography. This can be understood in the light of a particular way of understanding the work of his artist friend Chen Hongshou. Anne BurkusChasson (2002: 317) argues that: 'As a painter of historical narratives, Chen assumed the didactic role of the historian. However, in picturing an instructive event from the past, he tended to heighten its emotional aspect and focus on its transient, unknowable moments. The moral paradigm represented by the event thus lost its central importance. To use the critical terms of his contemporaries, Chen's predilection to depict emotion made his paintings like theatrical performances ... Emulating the anonymous illustrators of wood-block-printed books ... Chen depended on exaggerated figural gestures to invest a climactic narrative event with affective power.' Zhang Dai, by contrast, seems intent on divesting his portraits of any suggestion of theatricality or transience, but rather on ensuring that they appear as timeless statements of virtue, deed, or word, not individual emotion.

This consideration leads in turn to an understanding of Portraits as the attempt to merge what have been seen as two distinct types of portrait, the ritualistic and the commemorative. To some degree, and certainly in light of the manner and purpose of their original commisioning, before they were copied into Zhang Dai's book, these portraits appear to work within the tradition of portraiture associated with 'ancestor portraits,' wherein the images presented were to be, in Jan Stuart's words, both 'ritually charged and rigidly decorous' (1997: 17). ${ }^{33}$ In this context, verisimilitude was critical. Jan Stuart and Evelyn Rawski (2001: 82) cite the late Ming writer Jiang Yingke 江盈科 (1556-1605), a close associate of Yuan Hongdao, to the following effect in an essay

\footnotetext{
${ }^{33}$ As Stuart points out, this tradition of portraiture had a variety of terms: 'calling back the shadow' (zhuiying 追影), 'posthumous portrait' (yixiang 遗像), 'transmitted spirit' (chuanshen 傳神), 'longevity portrait' (shouxiang 壽像), 'happy spirit' (xishen 喜神), 'lifting the cloth' (jiebo 揭帛) 一referring to the raising of the shroud in order to paint the face-and 'multi-generational painting' (daitu 代圆). For an excellent full treatment of this topic, see Stuart \& Rawski (2001).
} 
entitled 'Seeking the Real' ('Qiu zhen' 求真) in which he compares theories about poetry with those about portraiture:

It [the poetic theory] is comparable to a painter of portraits (xiezhen chuanshen 真真傳神) who-be his subject's face beautiful or ugly, dark or light, fat or thin, slanty or straight, smooth pockmarked-wishes one thing only: to paint a portrait which is totally like, so that when the son sees it, he says, 'This is really my father' ... If such things as the facial features, eyes, cheekbones, chin, and so forth are not like, and the artist merely does a mechanical depiction based on the clothes and appurtenances ... imitating the ancients in every detail, but missing the appearance of his actual form, then the son will not recognize his father ... Such a work could not be considered a likeness, nor could it even be considered a painting.

If ancestral portraits needed to be 'real' in order, efficaciously, to serve their ritualistic purpose, commemorative portraits of the sort that provided Zhang Dai with another model for his work, by contrast, worked to different expectations. Books of such portraits, 'Genealogy Portraits' (puxiang 譜像), as Craig Clunas labels them (1997: 94), were mnemonic in purpose, designed to remind people of the great virtue, deed, or word of certain people of the past, in order to encourage emulation amongst present or future generations. As such, they sought not to provide realistic portraits of the men and women of the past in all their individuality, but rather to present timeless and iconic representations of particular moral values. By the mid and late $1680 \mathrm{~s}$, it seems, some forty years after his 'state collapsed, his family was destroyed' (guo po jia wang 國破家 $亡$ ), in the famous words of the preface to his Dream Memories of Taoan (Zhang Dai 2001: 3), it was no longer the quest for the authenticity of the individual that motivated Zhang Dai in his historiographical work, but more the comfort of the promise of immortality offered by the eternal categories of orthodox morality.

\section{Reference List}

Burkus-Chasson, A. 2002, 'Between Representations: The Historical and the Visionary in Chen Hongshou's "Yaji,", The Art Bulletin, vol. 84, no. 2: 315-33. 2010, Through a Forest of Chancellors: Fugitive Histories in Liu Yuan's Lingyan ge, an Illustrated Book from Seventeenth-century Suzhou. Harvard University Press, Cambridge, MA.

Cahill, J.. 1982, The Compelling Image: Nature and Seventeenth-Century Chinese Painting. Harvard University Press, Cambridge, MA.

Campbell, D. M. 2010, 'Flawed Jade: Zhang Dai's Family Biographies,' Ming Studies, no. 62: 25-55.

Cao Shujuan 曹淑娟. 2006, 'Yuanzhou yu zhouyuan-Wang Ruqian hufang shenfen de zhuanhuan yu juxian’ 園舟與舟園一汪汝謙湖舫身份的轉換與局限 [The Boat in the Garden and the Boat as Garden: Transitions and Limitations of Identity in Wang Ruqian's Boat Garden,' Qinghua xuebao 清華學報, vol. 26, no. 1: 197-235.

Clunas, C. 1997, Pictures and Visuality in Early Modern China. Princeton University Press, Princeton, NJ. 
2007, Empire of Great Brightness: Visual and Material Cultures of Ming China, 1368-1644.

University of Hawai'i Press, Honolulu.

Fisher, Tom. 1984, 'Loyalist Alternatives in the Early Ch'ing,' Harvard Journal of Asiatic Studies, vol. 44, no. 1: 83-122.

Goodrich, L. Carrington \& Chaoying Fang. (eds) 1976, Dictionary of Ming Biography, 1368-1644, 2 vols. Columbia University Press, New York \& London.

He Guanbiao 何冠彪. 1986, 'Zhang Dai bieming, zihao, jiguan ji zunian kaobian’ 張岱別名字號籍貫及卒年考 辩 [An Examination into Zhang Dai's Names, Place of Registration, and Date of Death], Zhonghua wenshi luncong 中華文史論丵, no. 3, 167-93.

Hegel, R. E. 1998, Reading Illustrated Fiction in Late Imperial China. Stanford University Press, Stanford.

2006, 'Dreaming the Past: Memory and Continuity Beyond the Ming Fall,' in Trauma and Transcendence in Early Qing Literature, (eds) W. L. Idema, W. Li \& E. Widmer. Harvard University Press, Cambridge, MA, \& London: 345-74.

Ho Koon-piu 1994, 'Should We Die as Martyrs to the Ming Cause?: Scholar-officials' Views on Martyrdom During the Ming-Qing Transition,' Oriens Extremus, vol. 37, no. 2: 123-51.

Hou Han shu 後漢書 [History of the Latter Han]. 1965, Zhonghua shuju, Beijing.

Hu Yimin 胡益民. 2002a, Zhang Dai pingzhuan 張岱評傳 [A Critical Biography of Zhang Dai]. Nanjing daxue chubanshe, Nanjing.

2002b, Zhang Dai yanjiu 張岱研究 [Research on Zhang Dai]. Anhui jiaoyu chubanshe, Hefei.

Hummel, A. W. (ed.) 1943, Eminent Chinese of the Ch'ing Period, 1644-1912. Government Printing Office, Washington.

Kafalas, P. A. 1998, 'Weighty Matters, Weightless Form: Politics and the Late Ming Xiaopin Writer,' Ming Studies, vol. 39: 50-85.

Kafalas, P. A. 2007, In Limpid Dreams: Nostalgia and Zhang Dai's Reminiscences of the Ming. EastBridge, Norwalk.

Legge, J. (trans.) 1960, The Chinese Classics. 5 vols. Hong Kong University Press, Hong Kong.

Leys, S. (trans.) 1997, The Analects of Confucius. W. W. Norton, New York \& London.

Nienhauser, W. H. (ed.) 1986, The Indiana Companion to Traditional Chinese Literature. Indiana University Press, Bloomington

Park, J. P. 2012, Art by the Book: Painting Manuals and the Leisure Life in Late Ming China. University of Washington Press, Seattle.

She Deyu 余德余. 2006, Dushi wenren一Zhang Dai zhuan 都市文人一張岱傳 [Metropolitan Man-of-letters: A Biography of Zhang Dai]. Zhejiang renmin chubanshe, Hangzhou.

Spence, J. D. 2005, 'Presidential Address: Cliffhanger Days: A Chinese Family in the Seventeenth Century,' The American Historical Review, vol. 110, no. 1: 1-10. 2007, Return to Dragon Mountain: Memories of a Late Ming Man. Viking, New York.

Struve, L. A. 1982, 'The Hsü Brothers and Semiofficial Patronage of Scholars in the K'ang-hsi Period,' Harvard Journal of Asiatic Studies, vol. 42, no. 1: 231-66. 1984, The Southern Ming, 1644-1662. Yale University Press, New Haven \& London. 1988, 'The Southern Ming, 1644-1662' in The Cambridge History of China: Volume 7: The Ming Dynasty, 1368-1644, Part I, (eds.) F. W. Mote \& D. Twitchett. Cambridge University Press, Cambridge: $641-725$.

Stuart, J. 1997, 'Calling Back the Ancestor's Shadow: Chinese Ritual and Commemorative Portraits,' Oriental Art, vol. 42, no. 3: 8-17.

Stuart, J. \& Rawski, E. 2001, Worshipping the Ancestors: Chinese Commemorative Portraits. Stanford University Press, Stanford.

Vinograd, R. 1992, Boundaries of the Self: Chinese Portraits, 1600-1900. Cambridge University Press, Cambridge.

Wakeman, F., Jr. 1984, 'Romantics, Stoics, and Martyrs in Seventeenth-Century China,' Journal of Asian Studies, vol. 43, no. 4: 631-65.

Watson, B. (trans.) 1968, The Complete Works of Chuang Tzu. Columbia University Press, New York.

Wu, K. T. 1943, 'Ming Printing and Printers,' Harvard Journal of Asiatic Studies, vol. 7, no. 3: 203-60.

Xia Xianchun 夏咸淳. 1989, Mingmo qicai一Zhang Dai lun 明末奇才一張岱論 [A Late Ming Genius-On Zhang Dai]. Shehui kexueyuan, Shanghai.

Zhang Dai 張岱. 1985, Langhuan wenji 琅嬛文集 [Paradise Collection], (ed.) Yun Gao 雲告. Yuelu chubanshe, Changsha. 1991, Zhang Dai shi wen ji 張岱詩文集 [Collected Prose and Poetry of Zhang Dai]. Shanghai guji chubanshe, Shanghai. 
2001, Taoan mengyi: Xihu Mengxun 陶㟟夢憶：西湖夢寻 [Dream Memories of Taoan: Dream Quest for West Lake], (eds) Xia Xianchun \& Cheng Weirong 程維㮡. Shanghai guji chubanshe, Shanghai. 2005, Yuyue ming yidai sanbuxiu tuzan 於越明一代三不朽圖贊 [Portraits of the Eminent Worthies Immortals of Zhejiang During the Ming Dynasty Whose Lives Embodied the Three Eternals]. Zhongguo dang'an chubanshe, Beijing.

Zhang Zetong 張則桐. 2009, Zhang Dai tan gao 張岱探稿 [Draft Explorations into Zhang Dai]. Fenghuang chubanshe, Nanjing.

Zhou Xibao 周錫保. 1984, Zhongguo gudai fushi shi 中國古代服飾史 [A History of Ancient Chinese Clothing]. Zhongguo xiju chubanshe, Beijing. 